\title{
Financial Liberalization, Reforms and Bank Performance: Evidence from Malaysian Islamic Banks
}

\author{
Yagoub Elryah \\ School of Southeast Asian Studies, Faculty of International Relations, Xiamen University, China. \\ Yagoub Elryah, PhD candidate; Institute of Southeast Asian Studies, Faculty of International Relations, Xiamen \\ University, No.422 Siming South Road., Xiamen,361005, P. R. China, Xiamen, Fijian, China.
}

\begin{abstract}
The regulatory reforms implementing by Malaysian government since 2010 have been enhancing the performance of Islamic banks. The purpose of this research is to provide empirical evidence concerning the impacts of liberalization and reforms on Islamic bank's performance in Malaysia. The posited hypothesis is there is significant relationship among? between financial liberalization, regulatory reforms and Islamic banks performance in Malaysia. Datum were collected from 16 Islamic banks. Online statistical datum used in this study were extracted from Bank Negara Malaysia (BNM), World Bank, IMF and financial report of the selected banks, we considered annual datum from 2002 until 2012. To test our hypotheses, we used panel regressions model to investigate the relationship between the Islamic banks performance and financial liberalization and reforms, although its relation with return on assets and equity on return was measured by Z-score. The findings indicate that financial liberalization and openness, assets, profitability, return on assets and inflation have statistically positive impacts on Islamic banks performances.
\end{abstract}

Keywords: Liberalization, Islamic Banks, Islamic law, Openness, Regulatory Reforms, Malaysia.

\section{Introduction}

The liberalization of financial system has had a huge impact on banking sector and economic structure of countries all over the world. Malaysian banking system which began in the conventional and since 1983 many Islamic banks has established. The rapid growth of the Islamic banking and finance in Malaysia are made possible with the full backing support by the Malaysian government. The government has provided a strong foundation for the industry to grow such as establishing the financial and legal platform for rapidly growth industry (Sukmana and Kassim, 2010). The banking liberalization intended to enhance the efficiency of the banks, improve the allocation of credits, stimulate savings and, thus, attain a higher economic growth (Beju D. G., and Ciupac-Ulici M., 2013).

Opening up a country's financial sector to global competition is the essence of financial liberalization. According to the doctrine, with financial liberalization, the banking institutions would be more efficient, allocating credit to the most productive sectors (Chow F. Y. and Eu C. T., 2009). The Islamic banks as financial institutions along with their products in facing liberalization and openness took some of the interest in the recent years (Ahmed Al-Ajlouni, 2002; Sundararjan \& Errico ,2002).

Islamic finance in Malaysia continues to demonstrate dynamic growth with a comprehensive Islamic financial system that is supported by robust regulatory, legal and Shariah governance frameworks, more than 100 Islamic banking products and services available in the industry. Innovative products and financial instruments that are aligned with the global Shariah principles have been issued in the global market (BNM, 2013). Thus, Malaysia started working closely with Arab regulators, especially those of Bahrain, the United Arab Emirates, the IMF, the Islamic Development Bank and the Basel committee, the IFSB issued a draft in 2005 on Basel 2 rules for Islamic institutions (Ibrahim Warde, 2010).

In recent times, the Islamic banks performance has been increasingly by the researchers (Zainal Aznam Yusof et al., 1995). Malaysia has emerged as one of the leading a hub of Islamic banking and finance in Islamic countries, and, therefore Islamic banking sector, however, has had difficulty maintaining this goal despite double-digit growth in both lending and assets. Islamic banks have added RM111.6 billion in assets over the past two years, bringing their share of total banking assets in Malaysia to 19.6\% in December 2012. Malaysia aims to boost the market share for Islamic banking to $40 \%$ by 2020 , it also wants to make the industry more international (BNM report, 2013). According to the 2013 Islamic finance development report published by the Islamic Development Bank, the global sukuk market has doubled since 2007, driven mostly by issuances in Malaysia, which had $\$ 170$ billion in outstanding sukuk and represented 68 percent of total global sukuk at the end of 2012.

Malaysia is one of the main markets where Islamic finance has a systemic importance due to the increasing market share of IIFS operating within the respective jurisdictions. Thus, the IIFS hold 20\% (IFSB report 2013) of total banking system assets as at end-2012, as illustrated in Chart 1.1.1. Breaking down the 
collective market share, the largest individual Islamic financial institution in the country contributes $4.7 \%$ to total banking assets.

The objective of this paper is to examine whether financial liberalization, reforms affect performance of 16 Malaysian Islamic banks over the period 2002 and 2012, which is the period after many Islamic banks operated and regulated the financial system.

The paper proceeds as follows. In next section we provide a short literature of the theoretical contributions that from background to our research. Section 3 describes the methodology and data employed in the study. Our empirical results are summarized and discussed in section 4. And the last section provides the research conclusion.

\subsection{Financial Liberalization and Banks Performance}

\section{Literature Review}

It is widely recognized that financial liberalization is an integral part of financial sector development. As such; policies on trade liberalization, interest rate deregulation, capital account opening may have an important implication on financial development and hence economic growth. However, a large body of literature to address the issue of the importance of financial liberalization in facilitating economic development and growth has been undertaken by many economists (see for example, Schumpeter, 1911; McKinnon, 1973; and Show 1973). (Beju D. G., Ciupac-Ulici M., 2013) studied the impact of liberalization process on banking system and informational efficiency of five banks from Eastern European countries. They used the Generalized Spectral Test of Escanciano and Velasco during 2001-2012. They found the exchange rate stability and monetary independence don't have an impact on banks efficiency and capital openness has a positive impact on banking system, while, the bank nonperforming loans to total gross loans have a significant and negative impact on banking system efficiency.

However, there are only a few studies that examined the financial liberalization and reforms and banks' performance (Alin M. and Bogdan C., 2013) analyzed the impact of financial liberalization and reforms on the banking performance in 17 countries from Central Eastern European CEE. They estimated bank performance and assessed its determinants. They found that banks from CEE countries with higher level of liberalization and reform are able to increase cost efficiency and eventually to offer cheaper services to clients. Banks from nonmember EU countries are less cost efficient but experienced much higher total productivity growth level, and large sized banks are much more cost efficient than medium and small banks, while small sized banks show the highest growth in terms of productivity.

During liberalization, banks may experience substantial gains, but they are also subject to the possibility of substantial losses or crisis as the financial system transitions from a controlled to an open system. Under this changing scenario, regulatory authorities are highly interested in measuring the performance of banks in terms of profitability, cost efficiency, asset quality, management efficiency, etc. to have a clear picture about the impact of financial reform program on banks. Banks also show keen interest on this since the atmosphere has been electrifying by the emergence of financial reform, financial innovation, and automation (Claudia et al., 2004). The reforms are designed to enable the banking system develop the required flexibility to support the economic development of the nation by efficiently performing its functions as the pivot of financial intermediation (Lemo, 2005).

\subsection{The Scenarios of Islamic Banks}

Malaysia's financial liberalization process was punctuated by several major turning points. The first one involved interest rate liberalization in 1978-1985 and 1991-1998. The second one was the economic recession (1985-1986) which led to a break in the process of interest rate liberalization. The third one was the accelerating financial liberalization (with the capital account opening in the 1990s) followed by a long period of high GDP growth. The fourth one was the 1997 Asian Currency Crisis which spread to the Malaysian currency and resulted in the re-imposition of selective exchange controls (Goh S. Khoon, 2007).

In 1999, the domestic banks were given the flexibility to form their own merger groups and to choose their own leader in each group to lead the merger process. By 2001, the domestic banking sector was subsequently merged in a few banks; the structural reforms after the East Asian Financial Crisis (EAFC) have reshaped the financial landscape. The financial system has become more diversified; the number of players in the financial system has changed significantly after the EAFC. The rationalization program has led to the formation of financial conglomerates (Chow F. Y. and Eu C. T., 2009).

There were limited literatures that discussed financial liberalization and its impact of banking performance; their empirical results are also rather controversial. Some authors, such as (Mattar Njie, 2006) he studied the impact of financial liberalization on bank spreads in Malaysia, he used the traditional two-stage regression approach to explain the determinants of bank spreads in Malaysia. He point that government through its intervention policies remains a major determinant of bank spreads in banking industry in Malaysia. The results suggested that the reforms promoted the development of financial system, which in turn has positive 
knock-on effects on the level of financial intermediation. (Shanmugam and Nair, 2003) studied the causes and the process of mergers and acquisitions in Malaysia, he found that this process contribute to the reduction of the banking services costs, the increase of efficiency and competition in banking industry.

Hassan, Sanchez and Safa (2013) studied the impact of financial liberalization and foreign bank entry of domestic Islamic bankse performance and credit availability to private sector. Their funding was that foreign Islamic banks pursue aggressive financing in host countries and earn higher net profit margin. The entry choice and existence of foreign banks are significant influenced by the banking system returns and favorable economic environment and discouraged by the higher tax policies. The entry decisions were not be significant influenced by the recent crises, that seriously affected the profitability of domestic Islamic banks. However, domestic Islamic banks performance depends on the domestic tax policies and economic conditions. They also find that credit availability to private sector suffered because of high tax and reserve rate.

Chow F. Y. and Eu C. T. (2009) assessed the link between financial liberalization and the performance of the Malaysian banking sector. They employed cost ratio analysis, chi-square test and logistic regression analysis to assess the allocative efficiency of the banking sector. Their findings indicate that Malaysian domestic banks' interest margins have not narrowed with financial liberalization and there is a significant relationship between credit growth and financial liberalization. (Goh S. Khoon, 2007) studied the effects of capital controls on the composition of capital flows and on macroeconomic variables in Malaysia. He found that the controls had no effect on the real macroeconomic variables such as GDP growth and the real exchange rate and the capital controls have enabled monetary independence in Malaysia, thereby facilitating economic recovery and providing a breathing space for the implementation of structural reforms.

Ahmed Al-Ajlouni (2008) examined the ability of Islamic banks in benefiting from the opportunities that may be provided by financial globalization and limits its threats, through assessing the capability of Islamic banks to meet the requirements and challenges of financial globalization. The result shows that the financial globalization will have negative effects on Islamic banks autonomy, profit margin and competitive position. It will also enhance the Islamic banks' ability to create new investments and liquidity management instruments and methods, and develop the existing ones.

\subsection{Reforms and Islamic Banks Performance}

Reforms in the Malaysia's Islamic banks started since December 2010, when the Basel Committee on Banking Supervision ("Basel Committee") finalized a package of measures to strengthen global capital and liquidity rules with the goal of strengthening the resilience of the global banking system. The Bank Negara Malaysia (BNM) supports the implementation of these reforms measures and will strengthen the existing capital and liquidity standards for banking institutions in Malaysia, bringing them in line with Basel III. The Bank targets to implement the reforms package in Malaysia in accordance to the globally-agreed levels and implementation timeline which provides for a gradual phase-in of the standards beginning 2013 until 2019. Following the reforms, financial intermediation activity has certainly experienced relative expansion. The bank deposits have increased from around $110 \%$ of GDP in 2009 to $134 \%$ in 2012. Opposite, the ratio of M3 to GDP reduce from $13 \%$ in 2006 to $9.53 \%, 11.9 \%, 9.17 \%, 6.76 \%$ in 2007, 2008, 2009, 2010 respectively (see Tabe1).

Table 1. Selected Monetary Ratio in Malaysia: 2005-2012

\begin{tabular}{cccc}
\hline Year & M2/GPD ratio & M3/RDP Ratio & Total bank Deposit/GDP Ratio \\
\hline 2005 & 125 & 10.5 & 117.7 \\
2006 & 129.3 & 13 & 114.6 \\
2007 & 125.2 & 9.53 & 109.4 \\
2008 & 119.6 & 11.9 & 110.8 \\
2009 & 139.2 & 9.17 & 131.1 \\
2010 & 133.6 & 6.76 & 127 \\
2011 & 138 & 14.32 & 128.2 \\
2012 & 141.2 & 8.96 & 134 \\
\hline Source: World Bank development indicators, 2014. &
\end{tabular}

In addition to strengthening the quality of capital, minimum capital requirements for banking institutions in Malaysia will be raised in line with the levels determined under Basel III. Banking institutions will also be required to hold a capital conservation buffer comprising common equity of $2.5 \%$ overand-above the regulatory minimum. Table 2 illustrates the new capital requirements, including buffers, against the Basel II 
standard underpinning the present risk-weighted capital adequacy framework and capital adequacy Framework for Islamic banks.

Table 2. New capital requirements of Islamic banks

\begin{tabular}{lccc}
\hline & $\begin{array}{c}\text { Common Equity } \\
\text { Tier 1 Capital Ratio }\end{array}$ & $\begin{array}{c}\text { Core Capital } \\
\text { Ratio (CCR) }\end{array}$ & $\begin{array}{c}\text { Risk-Weighted } \\
\text { Capital Ratio (RWCR) }\end{array}$ \\
\hline Basel III & $4.5 \%$ & $6 \%$ & $8 \%$ \\
Minimum & $+2.5 \%$ & & $10.5 \%$ \\
$\begin{array}{l}\text { Conservation buffer } \\
\text { Minimum plus conservation buffer }\end{array}$ & $7 \%$ & $8.5 \%$ & $8 \%$ \\
$\begin{array}{l}\text { Basel II } \\
\text { Minimum }\end{array}$ & $2 \%$ & $4 \%$ & \\
Source: Implementation of Basel III, (2010) Prudential Financial Policy Department, Islamic Banking and Takaful Department,
\end{tabular}
$\mathrm{BNM} / \mathrm{RH} / \mathrm{NT}$ 007-25.

In this context, our study differs from that of Alin M. and Bogdan C. (2013) in measuring the openness and liberalization levels. In that we use profitability ratios with no interest rates as an ethical condition of Islamic financing is delineated. Our study also differs from that of Hassan, Sanchez and Safa (2013) in their methods and their concentrated on the foreign bank entry in 21 selected Islamic countries. Further contribution of this paper is that, in addition to measuring liberalization and reforms, we analyze their relative contribution to Islamic banks performance in Malaysia.

The current study seeks similar evidence, which those recent studies have found, from a short term prospective, most studies tended to focus on measuring the Islamic banks performance of over time without linking them to financial reforms. The objective of this study is to examine the relationship between liberalization and reform and performance of the Islamic banks in Malaysia, to assess the statistical substantial deference, main hypotheses is created. Furthermore a hypothesis is created to quantify the linear impact of financial liberalization, openness on performance:

$\mathrm{H} 1$ :There is significant relationship between financial liberalization and Islamic banks performance in Malaysia. H2: Financial reform has significant leaner influence on Islamic banks performance.

\subsection{Data Sources and Sample Characteristic}

\section{Data and Methodology}

The purpose of this research is to provide empirical evidence concerning impact of liberalization and reform on Islamic banks performance in Malaysia. Online statistical data used in this study were extracted from Bank Negara Malaysia (BNM), World Bank, IMF and financial report of the selected banks; we considered annual data from 2002 until 2012. The total number of observations in the sample is 114. We will test the data using several techniques such as the skewness test, kurtosis, the Jarque Bera as well as the value of mean and median. The value of skewness will be equal to zero, the value of kurtosis should be three and the value of mean should be the same as the value of its median while the value of Jarque Bera should not high value of probability. We used two methods, first we used the Least Square method, then we used the standard unit root test which has to be performed first to check the stationary of our data, we check with the augmented Dickey-Fuller test and the Phillips-Perron test. The final sample of this study consisted of sixteen Islamic banks (see Table 3).

Table 3.List of Licensed of Malaysian Islamic Banks Included in the Data Sample

\begin{tabular}{llccc}
\hline No. & \multicolumn{1}{c}{ Name } & $\begin{array}{c}\text { Year of } \\
\text { establishment }\end{array}$ & Ownership & $\begin{array}{c}\text { Data available / } \\
\text { years }\end{array}$ \\
\hline 1 & Affin Islamic Bank Berhad & 2006 & $\mathrm{D}$ & 7 \\
2 & Al Rajhi Banking \& Investment Corporation & 2006 & $\mathrm{~F}$ & 7 \\
& (Malaysia) Berhad & 2008 & $\mathrm{D}$ & 5 \\
3 & Alliance Islamic Bank Berhad & 2006 & $\mathrm{D}$ & 7 \\
4 & AmIslamic Bank Berhad & 2005 & $\mathrm{D}$ & 8 \\
5 & Asian Finance Bank Berhad & 1983 & $\mathrm{D}$ & 11 \\
6 & Bank Islam Malaysia Berhad & 1999 & $\mathrm{D}$ & 11 \\
7 & Bank Muamalat Malaysia Berhad & 2005 & $\mathrm{D}$ & 8 \\
8 & CIMB Islamic Bank Berhad & 2008 & $\mathrm{D}$ & 5 \\
9 & Hong Leong Islamic Bank Berhad & 2005 & $\mathrm{D}$ & 8 \\
10 & HSBC Amanah Malaysia Berhad & 2005 & $\mathrm{~F}$ & 8 \\
11 & Kuwait Finance House (Malaysia) Berhad & 2007 & $\mathrm{D}$ & 6 \\
12 & Maybank Islamic Berhad & 2008 & $\mathrm{D}$ & 5 \\
13 & OCBC Al-Amin Bank Berhad & 2008 & $\mathrm{D}$ & 5 \\
14 & Public Islamic Bank Berhad & 2005 & $\mathrm{D}$ & 8 \\
15 & RHB Islamic Bank Berhad & 2008 & $\mathrm{~F}$ & 5 \\
16 & Standard Chartered SaadiqBerhad & & & \\
\hline
\end{tabular}

Source: Bank Negara Malaysia (23/01/2014), Ownership denotes if a bank is a domestically owned bank (D) or foreign-owned bank (F). 


\subsection{Variable Definition}

The dependent variable is bank's performance (BP); twenty one measures of bank performance are used in this study. The Cost efficiency (CF); total productivity index (TPI), Asset Share of Local-owned Banks (ASL-OB), Asset share of foreign-owned banks (ASF-OB), Profitability Indicator (PR), Change in annual average retail/consumer Price Level in per cent (CPL/per cent); Domestic Credit provided by banking system percentage of GDP (DC/GDP), Lending Rate minus Deposit Rate percentage (LR-DR\%), Credit Risk (CR), Liquidity Risk (LR), Bank's Size (BS), Private Credit of Banks as \% of GDP (PCB\%GDP), Liquid Liabilities as \% of GDP (LL\%GDP), Money Supply M2 /GDP Ratio (\%), Credit to Private Sector CPS/GDP\%, Currency Outside Banks COB/M2 Ratio (\%), Currency in Circulation CIC/M2Ratio (\%), Currency Outside Banks COB/GDP Ratio (\%), Net domestic credit to RGDP (NDC/RGDP)\%, Cash reserve ratio \%, and Liquidity ratio $\%$.

A number of explanatory variables were used as determinants GDP growth (GDPG); Inflation Rate (IR), measured as the annual growth of the GDP deflator.

To control for the impact of financial liberalization and reforms, an index of financial openness (KAOPEN) was introduced. The financial openness index, developed by Chinn and Ito (2002; 2008), measures the extent of capital controls based on the information from the IMF's Annual Report on Exchange Arrangements and Exchange Restrictions (AREAER).

\subsection{Empirical Specification}

The relationship between performance and financial liberalization, reforms is examined using a basic model using the ROA and ROE as depending variables. The econometric investigations with stochastic frontier analysis, this model includes cost efficiency, productivity growth and banks specific variables, banking system variables to estimate bank performance, which have been used in previous empirical studies. This model suggested by (Battese G, Coelli T, 1992). The model developed below is estimated using the random effects panel data approach. The equation is given as:

$$
\mathrm{BP}_{\mathrm{it}}=\alpha_{0}+\beta \mathrm{S}_{\mathrm{it}} \times \beta_{\mathrm{it}}+\mathrm{M}_{\mathrm{it}}+\mathrm{KAOPEN}_{\mathrm{it}}+\varepsilon_{\mathrm{it}}
$$

The explanation of the above variables is as follows:

$\mathrm{BP}_{\mathrm{it}}=$ banks' performance indicators, measured by two accounting-based performance indicators - ROA and ROE.

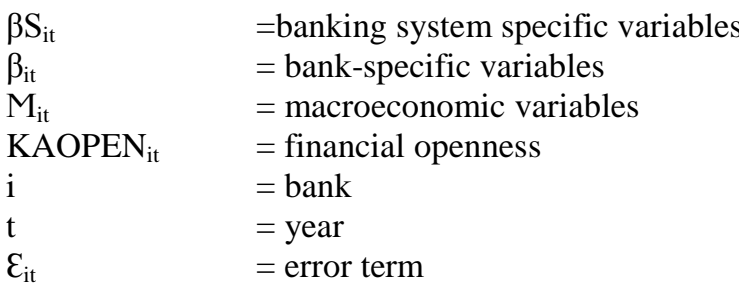

$\alpha$ is intercept, $\beta$ is regression coefficient and, $\varepsilon$ is an error term.

Second, we use Z-score to estimate the banks performance and financial openness degree of the banks.

$$
\mathrm{Z}=\frac{\mathrm{ROA}+\mathrm{E} / \mathrm{A}}{\sigma(\mathrm{ROA})}
$$

Where:

$\begin{array}{ll}\text { ROA } & =\text { Return on Assets } \\ \text { E/A } & =\text { Equity to Assets } \\ \sigma(\mathrm{ROA})=\text { Standard deviation of Return on Assets }\end{array}$

\subsection{Finding}

\section{Empirical results and discussion}

For the testing our hypothesis E-views is used. It requires a simple random sample from a population with a normal distribution and where mean is known. Regression analysis and Z-score are used for measuring the financial liberalization, reform and Islamic banks performance In order to test H1 regression analysis was run: bank's performance was taken as dependent variable and The cost efficiency (CF); total productivity index (TPI), Asset share of Local-owned banks (ASL-OB), Asset share of foreign-owned banks (ASF-OB), Profitability Indicator (PR), Change in annual average retail/consumer price level in per cent (CPL/per cent); Domestic Credit provided by banking system percentage of GDP (DC/GDP), Lending Rate minus Deposit Rate percentage (LR-DR\%), Credit Risk (CR), Liquidity Risk (LR), bank's size (BS), Private credit of banks as \% of GDP (PCB\%GDP), Liquid Liabilities as \% of GDP (LL\%GDP) GDP growth (GDPG); and Inflation rate (IR) taken as independent variables. The outcome from the analysis exhibited the coefficients for paths from independent variables to dependent variable. We used "Enter" method to generate Islamic banks in Malaysia from regression. 


\subsection{Unit Root Analysis}

First we begin by investigating the stationary in all variables by applying the Augmented DickeyFuller (ADF) test and the Phillips-Perron test to examine the null hypothesis which versus the alternative hypothesis. For cointigration each variables is integrated and more than or equal one. The ADF and the PhillipsPerron test are presented in the table below:

Table -4 Stationary Test

\begin{tabular}{lcc}
\hline $\begin{array}{c}\text { Individual unit root } \\
\text { process }\end{array}$ & \multicolumn{2}{c}{ Common unit root process } \\
\hline \multicolumn{1}{c}{ Variables } & ADF - Fisher Chi- & PP - Fisher \\
& square & Chi-square \\
\hline GDPG & 47.93281 & -3.0023 \\
& 0.0073 & 0.0083 \\
IR & 89.7463 & -1.2091 \\
& 0.0327 & 0.0034 \\
KAOPEN & -8.2373 & -0.9032 \\
& 0.4762 & 0.0201 \\
CF & 12.9542 & -2.7362 \\
& 0.0473 & 0.0023 \\
TPI & 58.3763 & -1.1352 \\
& 0.0128 & 0.0342 \\
ASL-OB & 54.3184 & -0.8415 \\
& 0.07452 & 0.0129 \\
ASF-OB & 83.0127 & -0.9103 \\
& 0.0238 & 0.0031 \\
PR & 27.4713 & -1.8372 \\
& 0.0231 & 0.0701 \\
CPL/ per cent & 42.9203 & -6.7321 \\
& 0.0472 & 0.0426 \\
DC/GDP & 18.2874 & -3.5462 \\
& 0.0827 & 0.0023 \\
LR-DR\% & 62.5737 & -1.0283 \\
& 0.1084 & 0.0831 \\
\hline
\end{tabular}

Stationary Test table -4 . Continue...

\begin{tabular}{lcc}
\hline $\begin{array}{l}\text { Individual unit root } \\
\text { process }\end{array}$ & \multicolumn{2}{c}{ Common unit root process } \\
\hline Variables & ADF - Fisher Chi- & PP - Fisher Chi-square \\
& square & -0.9242 \\
CR & 37.7465 & 0.0001 \\
& 0.0083 & -2.4931 \\
LR & 28.3784 & 0.0203 \\
& 0.0536 & -1.5294 \\
BS & 43.4072 & 0.0293 \\
& 0.0671 & -0.2783 \\
PCB\%GDP & 69.3762 & 0.4025 \\
& 0.1064 & -5.0343 \\
LL \% GDP & 19.2731 & 0.0901 \\
& 0.0104 & \\
\hline
\end{tabular}

Our results in table 4 show that most of the variables are significant at level 5\% for unit root except Lending Rate minus Deposit Rate percentage (LR-DR\%) and Private credit of banks as \% of GDP (PCB\%GDP) we will be dropped from our next estimation.

Table -5 Descriptive Analysis

\begin{tabular}{lccccccc}
\hline & GDPG & IR & KAOPEN & CF & TPI & ASL-OB & ASF-OB \\
\hline Mean & 4.732265 & 7.4378 & -0.282 & 6.746237 & 7.310382 & 8.734823 & 9.287348 \\
Maximum & 267387 & 8642 & 3.473 & 748993 & 984637 & 837782 & 187327 \\
Minimum & 7384 & 623 & -0.872 & 6732 & 9283 & 8273 & 9821 \\
Std. Dev. & 637834 & -0.742 & 1.834 & 928674 & 637864 & 927492 & 674872 \\
Skewness & 3.04764 & 1.078 & 0.0348 & 1.64763 & 2.64783 & 0.732834 & 0.02643 \\
Kurtosis & 6.64763 & 9.6373 & 2.7476 & 0.64786 & 15.63765 & 11.63762 & 8.64376 \\
Jarque-Bera & 16.6417 & 13.1035 & 2.5631 & 12.5403 & 9.54716 & 3.52601 & 4.5289 \\
Probability & 0.0031 & 0.0245 & 0.0374 & 0.0271 & 0.0001 & 0.0218 & 0.0032 \\
\hline
\end{tabular}


Descriptive Analysis Table -5 Continue...

\begin{tabular}{lccccccc}
\hline & PR & DC/ per cent & CPL/GDP & CR & LR & BS & LL \% GDP \\
\hline Mean & 3.74639 & 7.34983 & 2.2421 & 6.7539 & 4.3762 & 5.36081 & 1.72198 \\
Maximum & 92847 & 83462 & 1.2892 & 63092 & 72127 & 73082 & 83427 \\
Minimum & 53275 & 97383 & 0.3232 & 8372 & 52764 & 8367 & 73987 \\
Std. Dev. & 538649 & 10846 & 0.4816 & 639120 & 840218 & 9479219 & 749201 \\
Skewness & 0.2746 & 2.7492 & 0.78236 & 3.2943 & 8.7982 & 3.67543 & 0.6479 \\
Kurtosis & 8.647 & 3.6754 & 1.21889 & 2.5482 & 9.6478 & 2.5467 & 5.6347 \\
Jarque-Bera & 17.6748 & 9.67478 & 0.02791 & 0.6389 & 0.0034 & 0.6372 & 8.7436 \\
Probability & 0.0032 & 0.8317 & 0.9712 & 0.0013 & 0.0082 & 0.0023 & 0.0002 \\
\hline
\end{tabular}

Table 5 presents the sample banks' descriptive statistics; illustrate the responsiveness of performance of 16 Islamic banks in Malaysia from 2002 to 2012. It can be seen that the Islamic bank performance is statistically significant related to changes in reform and an openness, cost efficiency (CF), GDP growth (GDPG); Inflation rate (IR), total productivity index (TPI), Asset share of Local-owned banks (ASL-OB) and Asset share of foreign-owned banks (ASF-OB). This suggested that process quality measurement.

Additionally, the results revealed that there is statistically and positive relation between Islamic banks performance and profitability indicator, Credit Risk (CR), Liquidity Risk (LR), Bank's Size (BS), Private credit of banks as \% of GDP (PCB\%GDP), Liquid Liabilities as \% of GDP (LL\%GDP).

\subsection{LOS Analysis}

Table -7 OLS regression results

\begin{tabular}{|c|c|c|c|}
\hline years & Variables & ROA & E/A \\
\hline \multirow[t]{3}{*}{2002} & Coefficient & 0.0031 & 0.2847 \\
\hline & Std. err & 0.1023 & 0.4756 \\
\hline & $\mathrm{z}$-value & 0.1805 & 0.6372 \\
\hline \multirow[t]{3}{*}{2003} & Coefficient & 0.0435 & 0.0367 \\
\hline & Std. err & 0.2613 & 0.5736 \\
\hline & z-value & 0.6009 & 0.2834 \\
\hline \multirow[t]{3}{*}{2004} & Coefficient & 0.0742 & 0.0035 \\
\hline & Std. err & 0.8394 & 0.0367 \\
\hline & z-value & 0.3014 & 0.9482 \\
\hline \multirow[t]{3}{*}{2005} & Coefficient & 0.2832 & 0.0542 \\
\hline & Std. err & 0.3017 & 0.1845 \\
\hline & z-value & 0.8001 & 0.1031 \\
\hline \multirow[t]{3}{*}{2006} & Coefficient & 0.0026 & 0.0536 \\
\hline & Std. err & 0.0475 & 0.2748 \\
\hline & z-value & 0.6316 & 0.1062 \\
\hline \multirow{3}{*}{2007} & Coefficient & 0.3651 & 0.0353 \\
\hline & Std. err & 0.4732 & 0.7265 \\
\hline & z-value & 0.9234 & 0.2016 \\
\hline \multirow[t]{3}{*}{2008} & Coefficient & 0.0145 & 0.0453 \\
\hline & Std. err & 0.1736 & 0.7467 \\
\hline & z-value & 0.5173 & 03062 \\
\hline \multirow[t]{3}{*}{2009} & Coefficient & 0.1184 & 0.0264 \\
\hline & Std. err & 0.3848 & 0.0957 \\
\hline & z-value & 0.0143 & 0.0031 \\
\hline \multirow[t]{3}{*}{2010} & Coefficient & 0.0435 & 0.0375 \\
\hline & Std. err & 0.1834 & 0.2746 \\
\hline & z-value & 0.0042 & 0.0027 \\
\hline \multirow[t]{3}{*}{2011} & Coefficient & 0.7263 & 0.5827 \\
\hline & Std. err & 0.8362 & 0.9203 \\
\hline & z-value & 0.0046 & 0.0030 \\
\hline \multirow[t]{3}{*}{2012} & Coefficient & 0.0746 & 0.0415 \\
\hline & Std. err & 0.2847 & 0.245 \\
\hline & z-value & 0.0043 & 0.0016 \\
\hline
\end{tabular}

Table 7 shows the results of Z-score two samples for mean ROA and E/A. for the testing of our hypothesis means of Islamic performance. Through Z-score the Z-values which success in the accepting as it is less than value of Z-critical at 5\% level of significance. We notice that the Z-scores are higher than5\% level in the years 2002to 2008 where Islamic banking in Malaysia was not involved. Since 2008 many Islamic banks were established. The table also shows that there are a significant positive in years 2009, 2010, 2011 and 2012. 
Table -8 Islamic banks - Financial Deepening

\begin{tabular}{|c|c|c|c|c|c|c|c|c|}
\hline Year & $\begin{array}{l}\text { M2 /GDP } \\
\text { Ratio (\%) }\end{array}$ & $\begin{array}{c}\text { CIC/M2 } \\
\text { Ratio (\%) }\end{array}$ & $\begin{array}{l}\text { COB/M2 } \\
\text { Ratio (\%) }\end{array}$ & $\begin{array}{l}\text { CIC/GDP } \\
\text { Ratio (\%) }\end{array}$ & $\begin{array}{l}\text { COB/GDP } \\
\text { Ratio (\% }\end{array}$ & $(\mathrm{NDC} / \mathrm{RGDP}) \%$ & $\begin{array}{c}\text { Cash reserve } \\
\text { ratio } \%\end{array}$ & $\begin{array}{l}\text { Liquidity } \\
\text { ratio \% }\end{array}$ \\
\hline 2002 & 32.4 & 19.3 & 29 & 16.2 & 58.4 & 5493.2 & 3.2 & 13.2 \\
\hline 2003 & 40.2 & 28.1 & 28.1 & 28.1 & 55.2 & 7837.8 & 3.1 & 14.5 \\
\hline 2004 & 37.6 & 30.5 & 30.6 & 29.5 & 49.7 & 12293.7 & 2.3 & 57.1 \\
\hline 2005 & 38.1 & 33.0 & 36.1 & 38.4 & 60.1 & 13443 & 4.1 & 48 \\
\hline 2006 & 49.0 & 35.4 & 33.5 & 44.2 & 63.8 & 26837.3 & 6.2 & 29.4 \\
\hline 2007 & 51.2 & 38.7 & 41.6 & 39.1 & 48.6 & 18038.2 & 5.8 & 38.2 \\
\hline 2008 & 43.2 & 31.1 & 39.2 & 27.3 & 49.5 & 24483.8 & 4.7 & 44.2 \\
\hline 2009 & 50.4 & 38.0 & 44.0 & 39.6 & 66.1 & 27748.3 & 1.2 & 37.2 \\
\hline 2010 & 67.2 & 41.3 & 48.1 & 43.0 & 48.2 & 37298.7 & 7.8 & 58.3 \\
\hline 2011 & 58.3 & 46.4 & 48.6 & 38.1 & 69.0 & 48038.2 & 10.4 & 49.1 \\
\hline 2012 & 76.4 & 45.2 & 51.1 & 28.3 & 46.4 & 66483.8 & 11.8 & 59.2 \\
\hline
\end{tabular}

Table 8 shows that, the reforms is a significant and influence on financial deepening especially the years after 2008. Also the six variants of financial deepening presented from 2002-2007 by governor Zeti A. Aziz (2006) shows that there are decreasing pressure of variance measures of financial deepening during the period 2000-2006. After 2008 there are many Islamic banks established and the government authority initiated new reforms to the banking sector made significant impact on the Islamic banks performance in Malaysia.

\section{Conclusion}

The Malaysian Islamic banking system has undergone of major changes, thus, the authorities has stepped to reform and liberalize and deregulate sufficiency of in order to integrate the Islamic banking and finance with the advanced International Islamic finance. Now the Islamic banking and finance in Malaysia represent about $25 \%$ of the total of financial system, as the reforms have taken place, Malaysia covets to achieve $40 \%$ by 2020 .

This study was undertaken to assess the impact of financial liberalization and reforms on Malaysian Islamic banks performances. We used panel regressions model to investigate the relationship between the Islamic banks performance and financial liberalization and reforms. A total of 16 Islamic banks and 114 observations participated in the study. An annual data from 2002 until 2012 were used.

The results indicated that relationship between financial liberalization and Islamic banks performance had been found statistically significant. The findings from the current research suggest that relationship between financial liberalization and reforms were found is to be significant to Islamic banks performance in Malaysia found.

However, the results of this study are different from the study undertaken by (Mattar Njie, 2006), who found that the government through its intervention policies remains a major determinant of bank spreads in banking industry in Malaysia.

The above discussion also suggested that the authorities of BNM should consider integrating the activities between openness and process reforms, and consider the better regulators in striving toward higher Islamic banks performance. As competition intensifies, Islamic banks and institutions need to pay more attention to the increasing needs of customers, regulatory quality.

One of the most obvious implications of our results is that if Malaysia is to realize its target performance of Islamic banking it needs to create a reforms and high quality regulatory which will be suitable and meet the internationally accepted supervision requirements. It follows from this that financial reforms and regulatory designed to raise growth and performance for Malaysia as a top in Islamic banking and finance in near future. 


\section{References}

[1] Ahmed Al Ajlouni (2008). "Developing Strategies for Islamic Banks to Face the Future Challenges of Financial Globalization" Munich Personal RePEc Archive, 3.

[2] Ahmed Al-Ajlouni (2002) "the state and future of Islamic banking on the world economic scene" luncheon cohosted by Arab Bankers Association of North America and the Middle East Institute Washington D.C., 12-13.

[3] Alin Marius and Bagdan C, (2013) "Impact of liberalization on banking sector performance from Central and Eastern European countries" PLOS Journal.http://www.plosone.org/article/info\%3Adoi\%2F10.1371\%2Fjournal.pone.0059686

[4] Bank Negara Malaysia BNM 2011, 2012, 2013 reports.

[5] Beju D. G., Ciupac-Ulici M. (2013)“Does financial liberalization affect banking system?”.Revista Economica. 65, 5

[6] Chow F. Y. and EU C. T. (2009) "Banking sector stability and financial liberalization: some evidence from Malaysia, the Canadian Journal of Economics. 1,2. 17-29.

[7] Claudia, G., Philip, M., \& Edward, P. M. G. (2004).Analyzing the Determinants of Bank Efficiency: the Case of Italians Banks, Applied Economics, 36, 215-227.

[8] El-Gamal, M, (1998) "Can Islamic banking survive? A micro evolutionary perspective” Islamic economic studies. 5, 1,2, 3.

[9] Goh S. Khoon (2007). "Financial liberalization and Openness in Malaysia". Journal of Dissertation.1, 2.

[10] Hassan M. K., Sanchez B. and Safa M. F., 2013, Impact of financial liberalization and foreign bank entry of domestic Islamic banking performance, International Journal of Islamic and Middle Eastern Finance and Management. 6, 1. 7-42

[11] Ibrahim Warde (2010) Islamic Finance in the Global Economy Edinburgh University Press, ISBN: 0738627774, 9780738627776.

[12] Islamic financial stability report (2013) Islamic Financial Services Board. p15.

[13] Islamic Development Bank (2013), Islamic finance development report. Jeddah, Saudi Arabia, p8.

[14] Lemo, T. (2005), "Regulatory Oversight and Stakeholder Protection", Paper presented at the BGL Mergers and Acquisitions Interactive Seminar, held at Eko Hotels \& Suits. V. I.

[15] Mattar Njie (2006) "Impact of financial liberalization on bank spreads in Malaysian" Journal of Economic cooperation. 27.3 (2006).163-194.

[16] M. Kabir Hassan (2008) "Impact of financial liberalization and foreign bank entry on Islamic banking performance". Emerald Group Publishing Limited. 6,1. 7-42.

[17] Rozzani, N. and Rahman, R. (2013) "Determinants of bank efficiency: conventional versus Islamic" International Journal of Business and Management; July 2013, 8, 14, 98.

[18] Shanmugam B. and Nair M., 2003, Mergers and acquisitions of banks in Malaysia, Managerial Finance, Volume 30, Number 4, 2003, 1-18

[19] Sukmana, R. and Kassim, S. H. (2010) Roles of the Islamic banks in the monetary transmission process in Malaysia. International Journal of Islamic and Middle Eastern Finance and Management.3 (1), 7.

[20] Sundarajan, V and Errico, L. (2002). "Islamic financial institutions and products in the global financial system: key issues in risk management and challenges ahead" IMF working paper WP/01/192, Washington D.C: International Monetary Fund IMF.

[21] Zanial Y. Awang H. Ismail A. Lim C. and Sukhdave S. (1995). Financial reform in Malaysia. In G. Caprio, JR.I.Atiyasand J. A. HANSON financial reform theory and experience“. (pp. 276-320). New York, USA. 